\title{
Twin-screw Extrusion Processing of Plant-Based Blends Using Graded Levels of High Protein Fermented Soybean Meal (FSBM)
}

\author{
Parisa Fallahi ${ }^{1}$, Kurt A. Rosentrater ${ }^{2} \&$ K. Muthukumarappan ${ }^{1}$ \\ ${ }^{1}$ Department of Agricultural and Biosystems Engineering, South Dakota State University, Brookings, South \\ Dakota \\ ${ }^{2}$ Department of Agricultural and Biosystems Engineering, and Department of Food Science and Human \\ Nutrition, Iowa State University, Ames, IA, USA \\ Correspondence: Kurt A. Rosentrater, Department of Agricultural and Biosystems Engineering, and Department \\ of Food Science and Human Nutrition, Iowa State University, Ames, IA, USA. Tel: 1-515-294-4019. E-mail: \\ karosent@iastate.edu
}

Received: June 6, 2019

Accepted: June 21, 2019 Online Published: July 13, 2019

doi:10.5539/jfr.v8n5p1

URL: https://doi.org/10.5539/jfr.v8n5p1

\begin{abstract}
Fast-paced growth in global aquaculture has elevated concerns about the high costs of fish farming production and potential water pollution. Thus, finding eco-friendly and more sustainable alternative protein sources for fish diets is of vital importance to the industry. A twin-screw extrusion processing study was performed using three ingredient blends formulated with graded levels of high protein fermented soybean meal (FSBM) $(0,80 \%$ and $100 \% \mathrm{db}$ fishmeal replacement) along with calculated amounts of other ingredients to meet the rainbow trout diets' requirements. Increasing the FSBM content from $0 \%$ to $100 \%$ resulted in a substantial increase in brightness, greenness, and yellowness, and a decrease in bulk density, water absorption index, and unit density (UD) values of the extrudates by $12.5 \%, 73 \%, 30 \%, 7.3 \%, 27.5 \%$, and $10 \%$, respectively. Compared to the control diet (100\% fishmeal-based), extrudate moisture contents increased by $15.2 \%$ and $22 \%$ for the diets containing 80 and $100 \%$ FSBM, respectively; although no change was observed by increasing FSBM from 80 to $100 \%$. The highest water solubility index (WSI) was obtained for $80 \%$ FSBM; however, further increasing FSBM did not influence the WSI significantly. All extrudates exhibited low water activity and high pellet durability values (less than 0.5 and more than $99.5 \%$, respectively). The most buoyant extrudates were obtained using total FSBM inclusion, with UD and expansion ratio values of nearly $660 \mathrm{~kg} / \mathrm{m} 3$ and 1.3 , respectively. Overall, results indicated that FSBM could be a promising alternative protein in vegetable-based blends.
\end{abstract}

Keywords: extrusion, protein, soybean, fermentation

\section{Introduction}

In response to the burgeoning rate of world population growth, researchers continue to seek to provide an adequate and secure supply of food. Seafood provides many protein sources that can be used to help these needs. However, the sustainability of this valuable food source and the impact of edible marine fish overharvesting on ecosystems have become valid concerns. In 2009, the United States ranked third worldwide in consumption of fish and seafood, yet $80 \%$ of these products were imported, which makes it second only to oil imports (NOAA, 2010). In 2011, the total value of fishery product imports (i.e. edible and non-edible) was $\$ 30.8$ billion, which was $\$ 3.4$ billion more than that of 2010 (NOAA, 2012). Clearly, this sector of the economy is growing rapidly and has become very important. Aquaculture has the potential to reduce US dependency on imported seafood products and to provide a secure food supply for the global population in the next few decades. However, factors such as biological, technical and economic limitations impact the development of aquaculture. Considering the techno-economic feasibility of aquaculture production, feed cost is a primary concern (Pritchard, 1976). The main source of protein in aquafeeds, particularly for carnivorous species, comes largely from ground, ocean caught fishmeal due to its easy availability, high nutritional value and biological qualities in terms of providing required nutrients such as essential amino acids, fatty acids, and digestible energy (ADCP, 1983; FDS, 1994). Approximately two to six pounds of ocean fish are needed for the production of only one pound of farm-raised fish, which results in an average transfer efficiency of 25\% (Marine Aquaculture Task Force, 2007.). The increasing rate of global demand for aquaculture products, coupled with the depletion of wild fish stocks has 
elevated the cost of fishmeal, and consequently, diet prices (Amaya et al., 2007; Lim and Lee, 2009). Therefore, utilization of alternative protein sources can play a crucial role in achieving a sustainable and profitable aquaculture industry (Hardy \& Masumoto 1990; Rumsey 1993; Hardy 2010). The goal is to minimize feeding fish with other fish by substituting appropriate fishmeal replacers.

To date, many studies have reported the dietary replacement of fishmeal with different alternative proteins for various species to reduce the diet- cost (Fontainhas-Fernandes et al., 1999; Jauncey, 2000; Coyle et al., 2004; Naylor et al., 2005). Due to its abundance, availability, sustainability, nutrient composition, and relatively low cost, soybean meal is one of the most promising sources of plant-based proteins as a fishmeal replacer in fish diets. Soybean is an excellent source of protein and oil. Different forms of soy-based proteins including: full fat soybean, toasted defatted soybean meal, untoasted defatted soybean meal, and even soybean cake have been used in aquafeed production for decades.

Average protein levels in conventional soybean meal are near $48 \%$, and the average oil levels of defatted soybean meal are approximately 19\% (Van Eys et al., 2004); however, variation can occur due to processing variations and the variety of the seed. Although the $\omega-3$ fatty acids content of soy oil is $90 \%$ less than that of FM oil, it can be partially utilized in fish feed as an alternative oil source (Zhou et al., 2011). Despite their high nutritional value, competing with fishmeal (FM) protein and essential fatty acids is difficult, as soy products such as soybean meal and soy flour are deficient in some essential amino acids, particularly lysine and methionine (Wilson, 1989; Floreto et al., 2000), contain some digestion-inhibitors (i.e. trypsin inhibitors and phytates), and other antinutrients (AN) (i.e. glycinin, lectin, and non-starch polysaccharides).

The oldest commercial fish farming is actually related to trout species farming, out of which rainbow trout (Oncorhynchus mykiss) is one the most common farm raised species in the US (CAES, 1994). It is fairly easy-to-culture carnivorous species that effectively utilizes 25 to $35 \%$ fishmeal in the diet formulation as the primary protein source (Kim et al., 1991; Hardy, 2002; Cheng and Hardy, 2004). Numerous studies have demonstrated the effect of partial and total soybean meal (SBM) utilization as a dietary protein source for this fish species. Some of these studies have indicated positive performance characteristics with the potential of complete or partially replacement of fishmeal with soy products in fish feeds. The earliest incorporation of soybean meal in trout diets was performed by the Cortland research group in the early 1940s. They suggested that the trout which were fed with soybean meal in their diets had similar growth rates to those fed with meat-meal based diets. Moreover, incorporation of SBM resulted in a 50\% reduction in the trout feed-cost (Tunison et al., 1941). Many studies have shown that FM could be replaced with SBM in rainbow trout diet at the levels between 25 to $80 \%$ of the diet (Smith, 1977; Smith et al., 1988; Pongmaneerat and Watanabe, 1992). Olli et al. (1994) studied the effect of four differently processed soy products (solvent-extracted soybean meal, dehulled and solvent- extracted soybean meal, dehulled full-fat soybean meal, and soybean concentrate) on the growth performance of rainbow trout. They replaced high-quality fishmeal at different levels of $14,28,42$, and $56 \%$ with the soybean proteins and concluded that soybean products have the potential to be used in salmonid diets without negative effects due to the ANs. Kaushik et al. (1995) found that 33 to $100 \%$ replacement of fishmeal with soy protein concentrate had no impact on the growth rate of rainbow trout. In another study, the effect of 50\% and 100\% fishmeal replacement with SBM on rainbow trout growth performance was compared with those of two different control diets (Gomes et al., 1995). They suggested that not only the type of alternative protein source was important but the control diet with which the results were compared played a significant role. However, other research has reported contrasting results with regard to the effect of soy product inclusion on growth performance of aquadiets. For example, Floreto et al. (2000) reported that optimal growth rate for juvenile American lobster (Homarus americanus) could be achieved only with less than 50\% replacement of FM with SBM and multiple amino acid supplementations. El-Saidy et al. (2002) studied the potential of complete FM replacement with SBM for Nile tilapia fingerling and revealed that total replacement of FM with 55\% SBM and $0.5 \%$ lysine supplementation had no adverse effect on growth performance of Nile tilapia. Before them, Dabrowski et al. (1989) also observed a substantial decrease in essential amino acids absorption and growth rate of rainbow trout fed with diets including $25 \%, 50 \%$, and $100 \%$ soybean meal-protein as the fishmeal-protein replacer. Rumsey et al. (1993) explored the inclusion effects of five physiochemically treated soybeans (1-conventional solvent- extracted SBM; 2-special processed solvent-extracted SBM; 3enzyme-treated solvent-extracted SBM; 4- ethanol-extracted solvent-extracted SBM; 5-alkali-treated solvent-extracted SBM) on the growth performance rate for rainbow trout and suggested that soybean oligosaccharides are required for achieving maximum growth or nitrogen utilization by rainbow trout. For the special processed solvent- extract SBM, they used Aarhus Oliefabrik A/S procedure where the oligosaccharides were not alcohol extracted (Rumsey et al. 1993). 
Some other researchers observed that by using longer heat treatment, SBM could result in less trypsin inhibitor activity (TIA) and greater feed digestibility for fingerling channel catfish (Wilson and Poe, 1985; Perse et al., 2003). Later on, the effect of extrusion processing on two rainbow trout diets including 29\% FM $-25 \%$ SBM and $29 \% \mathrm{FM}-25 \% \mathrm{WF}$ were examined by Romarheim et al. (2006), who reported a negative influence on growth rate and feed conversion compared with those of FM-based diet. However, TIA in the diets decreased to an appropriate level for rainbow trout species upon extrusion. These contrasting results can be ascribed to factors such as the effect of technological treatments applied to the soybean meal or in general soy protein and the impact of feed production technology on the biological and physical qualities and nutrient availability of the feed. Essential minerals are also very important in balancing the fish metabolism and achieving normal growth (Watanabe et al., 1997). According to Hardy (2002), mineral supplementation of plant-based trout diets is essential. As mentioned, technological treatments applied to soybeans can influence the biological properties of the feed. Hence, exploring the feasibility of reducing of soybean ANFs has become attractive to the soybean industry in order to promote soy utilization in many feed industries.

Chemically and thermally pre-treatmened forms of SBM can produce products such as soy protein concentrate (SPC) and soy protein isolate (SPI), which contain nearly $70 \%$ and $90 \%$ protein (dry basis), respectively. The content of ANs such as trypsin inhibitors, isoflavones, and phytic acids will be changed during the SPC and SPI production processes. In fact, the thermal treatment applied in the SPC inactivates these ANFs, while the inactivation or reduction of the ANs in SPI is totally dependent on the type of the chemical treatment; furthermore, no thermal treatment is involved in the SPI process. Fermented soybean meal (FSBM) is a microbial treated form of SBM, and is rich in protein (? 56\%) and low in ANFs. Antinutritional levels in the FSBM are reduced during the enzymatic degradation and fungal fermentation, which provides many benefits against digestion issues (Kim et al., 1999; Hong et al., 2004). Moreover, the protein quality can be significantly higher than that of SPC due to the low processing temperatures during the microbial process. Over the past decade, there has been a growing interest in evaluating the effects of FSBM inclusion on animal diets, but very little published information addresses the use of FSBM in fish diets (Shimeno et al., 1994; Refstie et al., 2005; Zhou et al., 2011; Yuan et al., 2012). In the last two studies, researchers suggested that FSBM could replace up to $20 \%$ and 35\% FM in the diets of juvenile Black sea bream, Acanthopagrus schlegelii, and juvenile Chinese sucker, Myxocyprinus asiaticus species, respectively. Feed production technology also plays a key role in the quality of the aquafeeds. Since the late 1950s and 1960s, extrusion processing has become the most common technology in the aquaculture industry to produce floating feeds (Moscicki and van Zuilichem, 1983). Extrusion is a short-time cooking process, which takes place inside the barrel of the extruder, using moderate to high temperatures, high shear rates, low to moderate moisture contents, and high pressure conditions. Using thermo-mechanical energy input, the raw and semi-dry feed ingredients are mixed, conveyed, transferred, worked into a viscous, plastic-like dough, cooked, and then shaped upon exiting a die restriction, where shaping and expansion phenomena occur due to water latent heat energy and instantaneous changes in water state from liquid to vapor as a result of the pressure release, all of this in a relatively short time (Hardy, 2002).

In general, extrusion performance and product quality are influenced by several parameters including feed composition and water content, temperature profile in the barrel sections, screw compression ratio, screw speed, die dimensions, feeding and product mass flow rates, specific mechanical energy, and type of the extruder (Bhattacharya et al., 1997; Chauhan et al., 1998; Sun et al., 2002; Ding et al., 2005; Chevanan et al., 2007a). The intensive interactions among the high shear forces and temperatures, in conjunction with low to moderate moisture inside the extruder influences the ingredient structure at a molecular level, and will impact the physiochemical, biological, and nutritional properties of the extruded pellets, primarily due to thermal transitions of the macromolecular components of the feed formula(Guy, 2001). If properly controlled, the extrusion cooking process not only can enhance the functional properties of the feed, but inactivate the ANs, increase the digestibility and bioavailability of nutrients, and reduce the microbial counts in the feed (Edwards et al, 1994; Steel el al., 1995). Desired physical properties of the extruded aquafeed include high floatability, water stability, and pellet durability index (Wood, 1995). Appropriate unit density and expansion ratio of the feed depend on the eating preference of the specific species of fish, which results in three general categories of feed: floating (i.e. Nile tilapia), slow-sinking (i.e.: rainbow trout), and rapidly sinking (i.e. catfish). However, in the aquaculture industry, floatable feed is often more desired, since it can prevent water pollution and nutrient loss (Vens-Cappell, 1984), due to over feeding. High water stability of the extruded feed also plays important role in preventing quick dissolving of the feed, leaching nutrient, and water contamination. Additionally, the more expanded extrudates have been shown to have better digestibility, due to the increased gelatinization of starch in the feed (Ali, 1988; Gokulakrishnana and Bandyopadhyay, 1995; Rout, 1997; Chang and Wang, 1999). Variation in moisture content of the feed mixture and extrusion processing conditions influence the expansion, the unit 
density, and thus the porosity of the extrudates, all of which directly affect the floatability of the extrudates (Hardy, 2002). Also, the porous texture of expanded extrudates allow for rapid post-extrusion oil coating and absorption by the extruded pellets (Hardy, 2002).

Typically, twin-screw extruders can have the better performance for production of floating extrudates in comparison to single screw extruders, since this type of extruder can handle a wider range of feed blend properties, from low to high moisture, fat, fiber, protein, and starch contents, as well as various particle size distributions (Riaz, 2000). In addition, positive conveying of the material, better mixing, and more heat transfer surface area can be obtained in a shorter residence time and at a higher output rate for a twin screw extruder (Zuilichem and Stolp 1984; Harper, 1989; Shi and Utracki, 1992; Rauwendaal, 2004; Chevanan et al., 2007b). Moreover, the intermeshing self-wiping property of the twin screws has the advantage of self-cleaning of the machines, resulting in less raw blend waste. Indubitably, both physical and nutritional qualities of feeds contribute to desired growth performance in the fish, and is achieved as a result of proper processing conditions (Banerjee and Chakraborty, 1998; Lin et al., 1998; Mathew et al., 1999c; Rolfe et al., 2000) in combination with a well- balanced feed formulation (Faubion et al., 1982; Mathew et al., 1999a, b; Cavalcanti and Behnke, 2005a, b). Therefore, the evaluation of extrusion processing impacts on resulting properties of the feed is crucial. For example physical properties of the extruded DDGS-based Nile tilapia and yellow perch feeds have been thoroughly examined by Chevanan et al. (2007a,b,c, 2008, 2009, 2010); Rosentrater et al., (2009a,b); Rosentrater and Tulbek (2010); Kannadhason et al. (2009a,b, 2010); Ayadi et al. (2011a,b,c,d); Mjoun and Rosentrater, (2011); Fallahi et al. (2013). To our knowledge, no studies have yet been published specifically focusing on the processing of FSBM-based blends, neither in evaluating the growth performance nor extrusion processing behavior. Consequently, the goals of the current study were: 1 ) to produce extruded blends for juvenile rainbow trout (Oncorhynchus mykiss) using FSBM as an alternative dietary protein source, and 2) to evaluate the effects of FSBM inclusion on the physical properties of the FSBM-based extrudates.

\section{Materials and Methods}

\subsection{Blend Preparation}

Table 1 lists the percent ingredient composition (dry basis percent) for the two experimental diets for rainbow trout and the control blend. Two isonitrogenous $(39 \% \mathrm{db})$ experimental feed blends containing graded levels of microbial fermented soybean meal (FSBM) (where FSBM replaced $80 \%$ and $100 \%$ of the fishmeal, respectively)), with net energy content of $3.06 \mathrm{kcal} / \mathrm{g}$, , along with appropriate amounts of fishmeal (for diet 1with $80 \%$ FSBM), and other required ingredients (Table 1) were formulated. FSBM was procured from NutraFerma (Sioux City, IA); Menhaden fishmeal was purchased from Omega Protein Inc. (Houston, TX); corn gluten meal was from Consumers Supply Distributing Company (Sioux City, IA); wheat flour was purchased from Bob's Red Mill Natural Foods, Inc. (Milwaukie, OR); carboxyl methyl cellulose (CMC) was provided by USB Corporation (Cleveland, $\mathrm{OH}$ ); vitamin and mineral premixes were purchased from Lortscher Agri Service, Inc. (Bern, KS), and essential amino acids were provided from USDA. A control diet containing $100 \%$ fishmeal as the main dietary protein source was also prepared. Using a laboratory-scale grinder (Model s500 disc mill, Glenmills, Clifton, NJ), fishmeal was reground. The proximate compositions of the diets are given in Table 2.

\subsection{Extrusion Cooking Process}

An industrial-scale co-rotating, fully intermeshing, and self-wiping twin-screw extruder (Wenger TX-52, Sabetha, KS) equipped with a $30 \mathrm{hp}$ motor, a dry feeder, a continuous pre-conditioner, and steam and water injection ports was used. The raw feed ingredients were conveyed from the feed hopper into the preconditioner, where steam with an injection rate of $0.11-0.16 \mathrm{~kg} / \mathrm{min}$ was used to adjust the initial moisture content and temperature. While the conditioner's screw speed and feed rate $(20 \mathrm{~kg} / \mathrm{h})$ were kept constant, the moistened and pre-heated blends were conveyed into the extruder. The barrel of the extruder had L/D ratio of 25.5/1, and its twin screws each had a diameter of $52 \mathrm{~mm}$. As shown in Fig. 1, each screw was composed of 25 individual sections including: 4 conveying screws, 3 shear locks, 1 conveying screw, 1 conveying screw backward, 3 conveying screws, 1 conveying screw backwards, 4 conveying screws, 1 shear lock, 1 interrupted flight conveying screw, 1 conveying screw, 1 interrupted flight conveying screw, 1 conveying screw, 1 interrupted flight conveying screw, 1 shear lock, and a cone-shaped tip at the end point. This configuration was recommended by the manufacturer. 
Table 1. Ingredient components $(\mathrm{g} / 100 \mathrm{~g})$ of the feed blends.

\begin{tabular}{|c|c|c|c|c|}
\hline Components (\%db) & Control & Diet 1 & Diet 2 & \\
\hline PepSoyGen & 0.00 & 47.20 & 58.84 & \\
\hline Fish meal & 45.90 & 11.54 & 0.00 & \\
\hline Corn gluten meal & 28.07 & 23.72 & 22.53 & \\
\hline Whole wheat flour & 22.47 & 10.17 & 11.27 & \\
\hline $\mathrm{CMC}$ & 0.76 & 0.00 & 0.00 & \\
\hline Vitamin premix & 0.63 & 0.63 & 0.63 & \\
\hline Mineral mix & 0.00 & 0.25 & 0.25 & \\
\hline Oils & - & - & - & \\
\hline Supplements (total from below) & 2.17 & 6.49 & 6.47 & \\
\hline Stay-C & 0.63 & 0.63 & & 0.63 \\
\hline Choline & 0.00 & 0.00 & & 0.00 \\
\hline Phytase & 0.00 & 0.00 & & 0.00 \\
\hline DVAqua & 0.16 & 0.16 & & 0.16 \\
\hline Arginine & 0.00 & 0.00 & & 0.00 \\
\hline Lysine & 0.00 & 0.00 & & 0.00 \\
\hline Isoleucine & 0.00 & 0.00 & & 0.00 \\
\hline Histidine & 0.00 & 0.00 & & 0.00 \\
\hline Glycine & 0.00 & 0.00 & & 0.00 \\
\hline Methionine & 0.00 & 0.63 & & 0.63 \\
\hline Taurine & 0.00 & 0.00 & & 0.00 \\
\hline Sodium chloride & 0.63 & 1.14 & & 1.14 \\
\hline Potassium chloride & 0.76 & 0.89 & & 0.88 \\
\hline Mgnesium oxide & 0.00 & 0.13 & & 0.13 \\
\hline Calcium phosphate & 0.00 & 2.91 & & 2.90 \\
\hline$\overline{\text { Total }}$ & 100.00 & 100.00 & 100.00 & \\
\hline
\end{tabular}

Table 2. Proximate compositions of the feed blends (\% $\mathrm{db})$.

\begin{tabular}{llll}
\hline Component & Control & Diet 1 & Diet 2 \\
\hline Moisture & 9.51 & 6.22 & 5.45 \\
Crude Protein & 39.96 & 39.51 & 38.15 \\
Crude Fat & 16.0 & 15.99 & 15.98 \\
Crude Fiber & 0.36 & 0.36 & 0.36 \\
Ash & 2.03 & 4.93 & 4.93 \\
Other & 32.14 & 33.32 & 35.13 \\
\hline Total & 100 & 100 & 100 \\
\hline
\end{tabular}

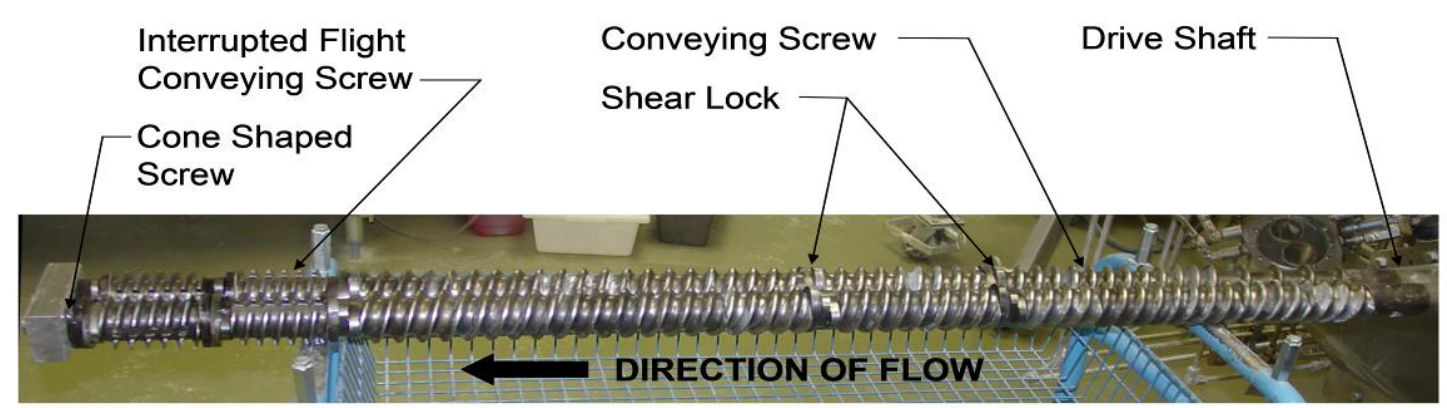

Figure 1. Twin screw configuration used in the extruder. 
The extruder barrel had 8 heating zones with an adjustable temperature profile from 15 to $90{ }^{\circ} \mathrm{C}$, which were varied during the experiment depending on the finished products properties, particularly cohesiveness. The extruder water rate was set at 0.11 to $0.19 \mathrm{~kg} / \mathrm{min}$. The extruder die section was composed of two circular die nozzles each with a diameter of $3 \mathrm{~mm}$ and a rotating blade cutter mounted at the end of the die section.

\subsection{Measurement of Processing Parameters}

A portable infrared thermometer (Model 42540, Extech Instruments Corporation, Waltham, MA) was used to measure the feed blend temperature at 3 different points of the extrusion cooking process including: inside the hopper, at the conditioner outlet, and at the die exit.

\subsection{Measurement of Extrudate Properties}

The extrudates were allowed to cool and then were dried in two steps: first they were kept at room temperature $(24 \pm 1)$ for $72 \mathrm{~h}$, and then a commercial-scale oven (Model TAH-500, Grieve Corporation, Round Lake, IL) was used for further drying at $45^{\circ} \mathrm{C}$ for another $24 \mathrm{~h}$. The physical properties of the dried extruded diets were analyzed following the methods described in the previous extrusion study by Fallahi et al. (2012).

Moisture content (MC): MC of the raw feed blends and extrudates was measured following AACC method 44-19 (2000), using a laboratory-scale oven (Fischer Scientific) at $135^{\circ} \mathrm{C}$ for $2 \mathrm{~h}$.

Water activity $\left(\mathrm{a}_{\mathrm{w}}\right)$ : A digital water activity meter $\left(\mathrm{a}_{\mathrm{w}}\right.$ Sprint TH-500, Novasina, Pfäffikon, Switzerland) was used to measure the $a_{w}$ of the extrudates. Switzerland).

Thermal properties: Using a digital thermal property analyzer (KD2, Decagon Devices, Inc., Pullman, WA), thermal properties of the extrudates in terms of conductivity $(k)$, diffusivity $(\alpha)$, and resistivity $(R)$ were determined. Pullman, WA).

Expansion ratio (ER): The diametral expansion of the diet extrudates was determined according to equation 1, following the method described by Conway and Anderson (1973) and van Zuilichem et al. (1975). A digital caliper (Digimatic Series Noo.293, Mitutoyo Co., Tokyo, Japan) was used to measure the diameter.

$$
\text { ER }(-)=\text { extrudate diameter }(\mathrm{mm}) / \text { die nozzle diameter }(\mathrm{mm})
$$

Unit density (UD): Following the method described by Jamin and Flores (1998), a cylindrical shape for the extrudates was assumed and UD was determined according the equation 2. Mass and diameter of the extrudates were measured using an analytical balance (AdventureAR 1140, Ohaus Corp. Pine Brook, NJ) and a digital caliper (Digimatic Series No. 293, Mitutoyo Co., Tokyo, Japan), respectively. The measurement was replicated 10 times.

$$
\mathrm{UD}\left(\mathrm{g} / \mathrm{cm}^{3}\right)=\text { mass of extrudate }(\mathrm{g}) /\left(\text { volume of the extrudate }\left(\mathrm{cm}^{3}\right)\right.
$$

Bulk density (BD): In order to estimate the magnitude of density and tightness of packed extrudates in storage room or transportation vehicle, BD was measured for a given bulk volume of $500 \mathrm{~cm}^{3}$ with a standard bushel tester (Seedburo Equipment Company, Chicago, IL) following USDA (1999) and according to equation 3:

$$
B D\left(\frac{g}{c m^{3}}\right)=(\text { mass of extrudates }(\mathrm{g})) /\left(500\left(\mathrm{~cm}^{3}\right)\right.
$$

Water absorption index (WAI) and water solubility index (WSI): Following the method recommended by Anderson et al. (1969), WAI and WSI of the diet extrudates were determined. Extrudate samples were finely ground to a powder with particle size of $\sim 150 \mu \mathrm{m}$ with a laboratory-scale grinder (Chemical Rubber Co, CRC, Germany). . $2.5 \mathrm{~g}$ of the powder along with $30 \mathrm{~mL}$ deionized water were placed in a $50 \mathrm{~mL}$ centrifuge tube. The mixture was intermittently shaken for $30 \mathrm{~min}$ and was centrifuged, using a laboratory-scale centrifuge (accuSpinTM 400, Thermo Electron Corporation) at $3000 \mathrm{x}$ g for $15 \mathrm{~min}$ at ambient temperature. Thereafter, the upper layer was separated and dried at $135^{\circ} \mathrm{C}$ for $2 \mathrm{~h}$ using a laboratory oven (Fisher Scientific). The mass of the remaining gel in the centrifuge tube was recorded. WAI and WSI were calculated according to equations 4 and 5, respectively:

$W A I(-)=$ mass of the remaining gel in centrifuge tube $(\mathrm{g}) /$ original mass of sample powder $(\mathrm{g})($

$$
\text { WSI }(\%)=\text { mass of the separated dried solid }(g) / \text { original mass of the sample powder }(g)
$$

Pellet durability index: Pellet durability index (PDI) is a measure of mechanical strength of extruded diets, which was determined following the standard method of ASAE S269.4 (ASAE, 1996). A PDI tester (model PDT -110, 
Seedburo Equipment Co., Chicago, IL) was used to tumble a given amount of extruded sample ( $200 \mathrm{~g})$ for 10 min, followed by sieving the tumbled extrudates with a No.6 screen. Then, PDI was calculated using equation 6: PDI (\%) = mass of extrudates after thumbling (g)/mass of the extrudates before thumbling $(\mathrm{g}) \times 100(6)$

Color: Using a spectrophotometer (Lab Scan XE, Hunter Lab, Reston, VA), color scores of the extruded diets (i.e. $\mathrm{L}^{*}$ (lightness/darkness), $\mathrm{a}^{*}$ (redness/greenness), and b* (yellowness/blueness)) were measured. Standard plates were used to calibrate the spectrophotometer according to the guidelines specified by the manufacturer, prior to the test.

\subsection{Nutrient Analysis}

Extrudates were dried at room temperature for $72 \mathrm{hr}$ and were subjected to proximate analysis for protein, fat, fiber, and ash content following the official Methods 990.03, 920.39, 978.10, and 920.48, respectively (AOAC 2003). Each property was measured in duplicate $(\mathrm{n}=2)$ for all raw ingredient blends.

\subsection{Statistical Analysis}

All the properties were measured in triplicates, but UD and ER, were randomly measured in 10 times. Microsoft Excel v.2010 and SAS v.9.0 software (SAS Institute, Cary, NC) were used to analyze the collected data. Analysis of variance with Type I error rate of 0.05 was performed to identify the significant differences between the control diet and plant-based protein diets. If present, post-hoc LSD tests were applied to determine where the specific differences occurred.

\section{Results and Discussion}

\subsection{Extrusion Processing Parameters}

Processing temperature (T): Table 3 presents the effect of experimental diet on temperature variations during the extrusion cooking process. As shown, FSBM incorporation at both levels (80 and 100\%) resulted in more than 7\% and $4.5 \%$ increase in conditioner temperature of $(\mathrm{Tc})$ and temperature at die exit $(\mathrm{Td})$, respectively. Several factors such as steam injection, heating barrel temperatures, as well as frictional heating could give proportional rise to the extruder temperature profile along the barrel length.

\subsection{Extrudate Properties}

Table 4 presents all results for the physical properties of the extruded diets. Considering the main effects of diets on extrudate physical properties, changing the inclusion levels of FSBM exhibited significant effects on almost all of the examined properties, except WSI, $\mathrm{a}_{\mathrm{w}}$, and thermal properties.

Moisture content: As shown in Table 4, increasing FSBM content of the blends from $0 \%$ to $80 \%$ and $0 \%$ to $100 \%$ resulted in an increase of $15.2 \%$ and $22 \%$ in the final moisture content of the extrudates, respectively; though there was no significant change between the raw moisture contents of diet 1 and diet 2 containing $80 \%$ and $100 \%$ FSBM. In general, moisture contents of the ingredient blend and the final extrudates play important roles in determining the ultimate quality of the products. The plasticizing effect of water influences the flowability (Ganesan et al., 2008) and the rheological properties of the dough; thus resulting changes in the physiochemical quality and the internal structure of the extrudates upon exiting of the die restriction. This mainly occurs due to the interactions among water and other chemical components of the blend, and is influenced by the severity of the extrusion processing conditions, especially the high temperatures, shearing forces, and high pressures developed during the process (Miller, 1985; Chevanan et al, 2007b). The internal structure and porosity of the final extrudates are formed due to water evaporation and subsequent expansion of the extruded matrices. Expansion is the product of instantaneous pressure drop and latent heat of vaporization occurring at the end point of the process upon exiting the die (Moore et al., 1990), and is influenced by the extent of starch and protein molecular transformation during the process (Nielsen, 1976). The more starch in the blend, potentially the more expansion of the extrudates is possible, which can be due to thermal transition of starch as a result of gelatinization (Chevanan, 2007b). 
Table 3. Treatment effects on extrusion processing parameters.

\begin{tabular}{lccc}
\hline & & Treatment & \\
Parameter & Control & Diet1 & Diet 2 \\
\cline { 2 - 3 } Processing temperature $\left({ }^{\circ} \mathrm{C}\right)$ & & & $25.78^{\mathrm{a}}$ \\
Feeder zone & $25.44^{\mathrm{b}}$ & $25.7^{\mathrm{b}}$ & $(0.18)$ \\
& $(0.20)$ & $(0.22)$ & $33.15^{\mathrm{a}}$ \\
Conditioner zone & $30.76^{\mathrm{b}}$ & $33.01^{\mathrm{a}}$ & $(1.19)$ \\
& $(0.53)$ & $(0.94)$ & $48.24^{\mathrm{a}}$ \\
Die zone & $46.02^{\mathrm{b}}$ & $48.07^{\mathrm{a}}$ & $(1.22)$ \\
\hline
\end{tabular}

Mean values among treatments followed by similar letters for a given dependent variable are not significantly different at $\mathrm{P}<0.05$. Values in parentheses are standard deviation.

Table 4. Treatment effects on extrudate physical properties.

\begin{tabular}{|c|c|c|c|}
\hline \multirow[t]{2}{*}{ Property } & \multicolumn{3}{|c|}{ Treatment } \\
\hline & Control & Diet1 & Diet2 \\
\hline $\mathrm{MC}(\%)$ & $\begin{array}{l}8.32^{b} \\
(0.12)\end{array}$ & $\begin{array}{l}9.81^{\mathrm{a}} \\
(0.79)\end{array}$ & $\begin{array}{l}10.18^{\mathrm{a}} \\
(0.79)\end{array}$ \\
\hline $\mathrm{a}_{\mathrm{w}}(-)$ & $\begin{array}{c}0.48^{\mathrm{a}} \\
(0.01)\end{array}$ & $\begin{array}{c}0.49^{\mathrm{a}} \\
(0.01)\end{array}$ & $\begin{array}{c}0.49^{\mathrm{a}} \\
(0.01)\end{array}$ \\
\hline $\mathrm{k}(\mathrm{W} /(\mathrm{m} . \mathrm{C}))$ & $\begin{array}{l}0.06^{\mathrm{a}} \\
(0.01)\end{array}$ & $\begin{array}{c}0.06^{\mathrm{a}} \\
(0.01)\end{array}$ & $\begin{array}{l}0.052^{\mathrm{a}} \\
(0.00)\end{array}$ \\
\hline $\mathrm{R}(\mathrm{m} . \mathrm{C} / \mathrm{W})$ & $\begin{array}{l}18.47^{\mathrm{a}} \\
(0.90)\end{array}$ & $\begin{array}{l}17.92^{\mathrm{a}} \\
(1.04)\end{array}$ & $\begin{array}{l}18.78^{\mathrm{a}} \\
(0.74)\end{array}$ \\
\hline$\alpha\left(\mathrm{mm}^{2} / \mathrm{s}\right)$ & $\begin{array}{l}0.16^{\mathrm{a}} \\
(0.01)\end{array}$ & $\begin{array}{l}0.16^{\mathrm{a}} \\
(0.01)\end{array}$ & $\begin{array}{c}0.17^{\mathrm{a}} \\
(0.01)\end{array}$ \\
\hline ER (-) & $\begin{array}{l}1.18^{\mathrm{b}} \\
(0.08)\end{array}$ & $\begin{array}{l}1.24^{\mathrm{a}} \\
(0.04)\end{array}$ & $\begin{array}{c}1.30^{\mathrm{a}} \\
(0.07)\end{array}$ \\
\hline UD $\left(\mathrm{kg} / \mathrm{m}^{3}\right)$ & $\begin{array}{c}731.70^{\mathrm{a}} \\
(100.11)\end{array}$ & $\begin{array}{c}682.105^{b} \\
(46.75)\end{array}$ & $\begin{array}{l}658.91^{b} \\
(67.93)\end{array}$ \\
\hline $\mathrm{BD}\left(\mathrm{kg} / \mathrm{m}^{3}\right)$ & $\begin{array}{c}572.15^{\mathrm{a}} \\
(1.30)\end{array}$ & $\begin{array}{c}544.02^{b} \\
(8.49)\end{array}$ & $\begin{array}{r}530.16^{\mathrm{c}} \\
(2.49)\end{array}$ \\
\hline WAI (-) & $\begin{array}{l}3.48^{\mathrm{a}} \\
(0.06)\end{array}$ & $\begin{array}{l}2.88^{b} \\
(0.22)\end{array}$ & $\begin{array}{l}2.52^{\mathrm{c}} \\
(0.12)\end{array}$ \\
\hline WSI (\%) & $\begin{array}{l}14.81^{b} \\
(0.24)\end{array}$ & $\begin{array}{l}18.32^{\mathrm{a}} \\
(3.04)\end{array}$ & $\begin{array}{c}16.46^{\mathrm{ab}} \\
(0.73)\end{array}$ \\
\hline PDI (\%) & $\begin{array}{l}99.46^{\mathrm{c}} \\
(0.05)\end{array}$ & $\begin{array}{l}99.59^{\mathrm{b}} \\
(0.08)\end{array}$ & $\begin{array}{l}99.84^{\mathrm{a}} \\
(0.07)\end{array}$ \\
\hline$L^{*}(-)$ & $\begin{array}{l}22.36^{\mathrm{b}} \\
(0.21)\end{array}$ & $\begin{array}{l}22.56^{\mathrm{b}} \\
(0.59)\end{array}$ & $\begin{array}{l}25.16^{\mathrm{a}} \\
(0.46)\end{array}$ \\
\hline $\mathrm{a}^{*}(-)$ & $\begin{array}{l}5.51^{\mathrm{c}} \\
(0.10)\end{array}$ & $\begin{array}{l}7.52^{b} \\
(0.26)\end{array}$ & $\begin{array}{l}9.55^{\mathrm{a}} \\
(0.31)\end{array}$ \\
\hline$b^{*}(-)$ & $\begin{array}{l}9.00^{\mathrm{c}} \\
(0.21)\end{array}$ & $\begin{array}{l}9.91^{\mathrm{b}} \\
(0.27)\end{array}$ & $\begin{array}{l}11.72^{\mathrm{a}} \\
(0.30)\end{array}$ \\
\hline
\end{tabular}

$\overline{\mathrm{MC}}$ is moisture content; $\mathrm{a}_{\mathrm{w}}$ is water activity; $\mathrm{K}$ is thermal conductivity; $\mathrm{R}$ is thermal resistivity; $\alpha$ is thermal diffusivity; ER is expansion ratio; UD is unit density; BD is bulk density; WAI is water absorption index; WSI is water solubility index; PDI is pellet durability index; $\mathrm{L}^{*}$ is brightness /darkness; $\mathrm{a}^{*}$ is redness/greenness; $b^{*}$ is yellowness/blueness; Parentheses indicate \pm 1 standard deviation; Means followed by similar letters for a given dependent variable are not significantly different at $\mathrm{P}<0.05$ among treatments. 
Clearly, the behavior of starch and protein components of the blend in response to extrusion processing effects can vary depending on their nature and inclusion ratio (Miller 1985; Riaz, 2000; Mercier et al., 1989). The more moisture content of the blend may result in less expansion and higher moisture content of the extrudates, depending upon the water holding capacity of the extrudate's matrix (Chevanan, 2007b). Therefore, it can impact the cohesiveness of the product, most probably due to the internal liquid-bridge formations among the particles (Johansson, 1978), and consequently can affect the WSI and WAI of the extrudates (Rolfe et al., 2001; Chevanan, 2007b). Additionally, moisture content of the extrudates impacts the storage stability and shelf life of the extrudates (Rolfe et al., 2001), especially the free water which is present.

Water activity $\left(\mathrm{a}_{\mathrm{w}}\right)$ : Water activity of a biological material represents the amount of unbound water (free) that can easily participate in physiochemical reactions, and is freely available to microorganisms. Knowledge about the water activity of a material helps to predict the shelf life and potential for microbial spoilage. Also, it can influence the enzyme activity, lipid oxidation, color, and aroma of the biological material. Hence, it is one of the crucial considerations for biological material safety. The strength of the water bound to the other molecules in a material influences the quantity of the $a_{w}$ of that substance. Assuming $a_{w}$ is the ratio of escaping tendency of water in a system to that of pure water at the same thermodynamic condition (e.g. temperature and pressure) (Koop et al., 2000). If water molecules are tightly bound to the other molecules in a material, they will not be able to elude from the substance in the form of vapor, and thus no vapor pressure will be released. However, $a_{w}$ can change depending upon the temperature, since the temperature influences the water binding strength of materials (Higl et al., 2007). In general, the lower water activity of a food or feed material, the less risk of spoilage (Chevanan, 2009). In this study, inclusion of FSBM did not impact the $a_{w}$ of the extrudates (Table 4). The average value of the water activity for all the extrudates was less than 0.5 indicating a long shelf life and low risk of microbial spoilage for the extrudates.

Thermal Properties: As shown, varying levels of FSBM had no significant effect on thermal characteristics of the extrudates compared to those of the control diet (Table 4). Thermal properties of materials can vary depending upon the materials natural chemical and physical structure. In thermal processing, the ability of materials to transfer the heat energy (e.g. thermal conductivity), to halt the heat flow (e.g. thermal resistivity), or to store the heat energy (e.g. thermal diffusivity) can impact the processing parameters as well as the product properties. Knowledge about the relation between the thermal properties of both raw ingredient blend and extruded blends allow us to anticipate the materials' thermal behaviors, and thus to improve the formulation and control the process conditions better in order to achieve a high quality product (Blanche and Sun, 2004). Thermal conductivity of a material indicates its potential for transferring heat through itself due to conduction only, and the driving force is just the temperature gradient. Thermal conductivity of a substance varies depending on its temperature and density; therefore, the required times for post-extrusion drying and cooling processes could be predicted by determining the extrudate thermal conductivity during the heat transfer between the extrudate surface and center, the correspondent temperature difference, and the void spaces of the extrudate (i.e. porosity) (Bouvier and Brisset, 2006). It is expected that with increasing extrudate porosity, the $\mathrm{k}$ value of the extrudate decreases, since $\mathrm{k}$ of the air trapped inside the extrudate is significantly lower than those of the extrudate's constituents. Thus, the $\mathrm{k}$ value of a material is also dependent on its composition. For example, the $\mathrm{k}$ value of air is $0.0294 \mathrm{~W} / \mathrm{m}^{\circ} \mathrm{C}$ at $30^{\circ} \mathrm{C}$, while reported values for starch and protein are $0.277 \mathrm{~W} / \mathrm{m} .{ }^{\circ} \mathrm{C}$, and $0.249 \mathrm{~W} / \mathrm{m} .{ }^{\circ} \mathrm{C}$, respectively (Choi et al., 1985). It is clear that the more an extrudate expands, the lower the thermal conductivity (Mariam, 2008). In another study, Heldman (2003) postulated that heat processing can reduce the thermal conductivity of food materials, primarily because of protein and starch transformations. The presence of hydrophobic constituents in the blend affects the density and thus thermal conductivity of the extruded material (Mariam, 2008). Thermal resistivity $(\mathrm{R})$ is a time dependent parameter which varies as a function of density and temperature difference across the material (Arambula-Villa et al., 2007). Being low heat conductive and high heat resistant, the raw blend may require longer time for cooking. The materials with lower heat conductivity and diffusivity are more protected against the external thermal sources which make them to be more stable (Ayadi et al. 2011b).

In another twin-screw extrusion study carried out for production of complete vegetable-based yellow perch diet (Fallahi et al., 2013), a direct relation between $\alpha$ and ER values of the extruded diets was observed which could be attributed to the more porous structure of expanded extrudates. Because, thermal diffusivity of the air trapped in the porous body of the extrudates is substantially ( 2 times) larger compared to those of the protein and starch components of the extrudates (Mariam et al., 2008).

Expansion ratio (ER): The resulting data revealed that FSBM incorporation led to production of more expanded feed. Inclusion of $80 \%$ and $100 \%$ FSBM increased the ER by 5\% and 10\%, respectively, although changing 
FSBM incorporation level had no statistically significant effect on the extrudate's ER (Table 4). ER is one of the most important quality parameters for fish feed extrudates. As mentioned earlier, the main driving force for extrudate expansion is pressure gradient during the water evaporation upon exiting the die section which causes a liquid-vapor phase transition and thus creation of air bubbles in the extrudates structure (Moore, 1990; Chevanan et al., 2007a), and is directly related to the extrudate buoyancy and fragility (Rosentrater et al., 2009a, b). The magnitude of extrudate ER can vary in response to several variables including: feed blend moisture content, ingredient conditions, die configuration, extruder throughput, pseudoplastic behavior of melted stream, and material residence time (Fan et al., 1994; Mitchell et al., 1994; Bouzaza et a., 1996; Chevanan et al., 2007a; Tumuluru and Sokhansanj, 2008). The shear thinning behavior of the melted dough in the extruder will result in a substantial decrease in the apparent viscosity of the dough which in turn will influence the magnitude of pressure gradient and ultimately puffing degree of the extrudates (Rosentrater et al., 2005; Chevanan et al., 2007a). Basically, the more water present in the blend can cause more viscosity reduction, it can reduce friction between the screw and the barrel, it can decrease pressure inside the die, it also facilitates the melted dough flow through the die section, and thus reduces the extent of extrudate expansion primarily because of lubricating properties of water (Mjoun and Rosentrater, 2011). On the other hand, the blend with higher starch content is prone to have more elastic and shear thickening behavior which causes a larger pressure gradient at the ending section (e.g. die) and more extrudate expansion. This happens mainly due to amylose molecular transformation and gelatinization (Nielsen, 1976; Sokhey et al., 1994; Ibanoglu et al., 1996; Lin et al, 2000). Various starch sources may exhibit different effects on the extrudates, depending upon the molecular structure and type of the starch and proteins present in the matrix (Kannadhason et al, 2009a). A positive effect of barrel temperature on extrudate ER was observed by Kim et al (1989) who recommended that higher temperature caused more starch gelatinization as well as super-heated steam excretion and consequently more expansion. The more expended extrudates have more accessible active sites for digestive enzymes (Rout, 1997). Where extrusion of starchy blends results in more expanded products, extrusion of proteinaceous blends leads to production of extrudates with more porous texture, primarily because of unfolded structure of protein molecules (e.g. denaturation) ( Sandra and Jose 1993; Chevanan et al., 2007a).

Unit density (UD): Unit density is another crucial property of the extrudate, which is inversely related to the ER, and it impacts the floatability of the extruded blends (Oliveira et al., 1992). FSBM incorporation decreased the UD of the extrudates curvilinearly (Table 4). Total replacement of FM with FSBM (i.e. diet 2) decreased the UD by nearly $9.5 \%$, while partial replacement of FM resulted in a $6.8 \%$ decrease in UD. However, changing levels of FSBM inclusion from $80 \%$ to $100 \%$ did not exhibit statistically significant influence on the products' unit density. FSBM inclusion at both levels resulted in buoyant products with UD values $<1.0 \mathrm{~kg} / \mathrm{m} 3$. As was expected, UD and ER values were inversely related (Colonna et al., 1989,), and all the extrudates did float. Extrusion conditions and interactive effects of several correspondent variables can influence extrudate UD values. For example, Tumuluru and Sokhansanj (2008) proposed that MC of the blend contributed not only to binding gelatinized starch, denatured protein and other ingredients of the diet but also toward the unit density of the extrudates. They also observed that barrel temperature, screw speed, and die L/D could impact the buoyancy of the extruded products.

In an earlier research work conducted by Chevanan et al. (2007a), postulated that while barrel temperature negatively affected extrudate unit density, moisture content had not considerable impact on this property. Bhattacharya and Hanna (1986) also reported similar trends for the effect of MC and barrel temperature on UD of the extrudates. They recommended that increasing barrel temperature progressively reduced the UD, which could be attributed to the shear thinning effect, higher temperatures and a subsequent increase in ER of the extrudate. The amount of conditioner steam and extruder water added during the extrusion process to adjust the MC are also factors affect UD values (Rosentrater and Tulbek, 2010; Fallahi et al., 2013).

Bulk density (BD): Bulk density of any kind of processed materials (including biological products) plays a vital role in cost estimation of the product. Transport and storage costs, decisive factors in product final cost, are a function of bulk density, which varies with size, shape, and ER of the extrudates (Chevanan et al., 2007a), and thus can strongly affect the required storage space (Guy, 2001; Rosentrater 2006), and transportation expense. Clearly, the extrudates with higher BD require less space for storage and transportation systems which reduces the associated costs. As shown in Table 4, increasing levels of FSBM incorporation decreased the BD of the extrudates. Using $80 \%$ and $100 \%$ FSBM as the FM replacer led to a 5\% and $7.3 \%$ decrease in the BD of the product, respectively. Changing FSBM inclusion level from $80 \%$ to $100 \%$ resulted in $2.5 \%$ decrease in BD. Our observations also indicated that there was a converse and a direct relationship between the ER and UD and ER and BD of the FSBM-based extrudates, respectively. Highest floatability was observed for extrudates produced 
from the complete FSBM-based diet (i.e. diet 2) which had the highest ER, lowest UD and BD of 1.30 (-), $658.91\left(\mathrm{~g} / \mathrm{cm}^{3}\right)$, and $530.16\left(\mathrm{~g} / \mathrm{cm}^{3}\right)$, respectively.

Water absorption index (WAI): Table 4 shows that FSBM inclusion at both levels resulted in a progressively decrease in the WAI. Utilization of $80 \%$ FSBM resulted in a $17.24 \%$ decrease in WAI; further increasing FSBM to $100 \%$ reduced the WAI by $27.6 \%$. As depicted in Table 4, ER and WAI of the extrudates were inversely related. This indicated that the more expanded extrudates absorbed less water. Our observations were in contrast with what Adeparusi and Famurewa (2011) suggested. Basically, WAI implies the amount of water absorbed by the starch components of the extrudates which were not affected by extrusion processing and thus retained their native structures (Mason and Hoseney, 1986; Govindasamy, 1996; Chevanan et al., 2007a). Mjoun and Rosentrater (2011) indicated that WAI of the blends, where the starch was not the only component, indicated the water holding capacity of the biopolymers and proteins present in the blend. Other researches recommended that variation in the WAI values reflects the structural modification of the blend macromolecular constituents. They believed that the main reasons for this structural modification are gelatinization of starchy components as well as denaturation of protein ingredients (Badrie and Mellowes, 1991; Chevanan et al., 2007a; Rosentrater et al., 2009a, b). Apparently, the greater the WAI of the extrudates can be attributed to less molecular weight reduction of amylose and amylopectin molecules during extrusion processing.

Water solubility index (WSI): While WAI was related to the quantity of the undamaged portion of the starch component of the ingredient blend, WSI directly refers to the extent of transformed starch (Harper 1981) and denatured protein (Colonna and Mercier, 1983) during extrusion processing. It has been shown that temperature elevation during extrusion processing increases WSI as a result of starch depolymerization (Anderson et al 1982). As mentioned earlier, depolymerization primarily happens due to reduction of amylose and amylopectin length. In extrusion cooking process, depolymerization of the macromolecules is strongly influenced by the interactive effect of high temperature, pressure rise, shearing forces, and water plasticization (Menegassi et al., 2011; Anderson et al., 1982). In our experiments, as FSBM increased, WSI increased curvilinearly. Inclusion of $80 \%$ FSBM significantly increased WSI by $23.7 \%$ at $\alpha=0.05$. Compared to that of the fishmeal-based diet; further increasing of FSBM to $100 \%$ reduced WSI by $10 \%$ compared with that of diet1. However, inclusion of FSBM at either level did not statistically influence the WSI values of the extrudate. Furthermore, WAI and WSI values of the FSBM-based extrudates were inversely correlated (Anderson et al., 1982).

Pellet durability index (PDI): Generally, extrudates are transported and stored in large bags or bins until use, when the distribution can be performed either manually or mechanically. Therefore, the resistance of the extrudates against abrasion and breakage is very important in order to avoid product wastage, nutrient loss, water pollution, and subsequent economic losses.

Indeed, intensity of the heat transfer and structural alteration of starch (at molecular level), influenced by the synergistic effects extruder high temperature and free water content of feed blend affect the durability of extrudates (Colonna et al., 1989; Chevanan et al., 2007a; Rosentrater et al., 2009a, b). FSBM incorporation significantly increased the PDI values of the extrudates (Table 4). This increasing PDI trend may be attributed to the FSBM protein characteristic. The structural alteration of FSBM protein during the extrusion process could affect water distribution in the produced matrix, and consequently influence the expansion and binding properties of the extrudates (Bhattacharya, 1997; Bhattacharya et al., 1986; Fernandez-Gutierrez et al., 2004). The high PDI values of above $99.5 \%$ confirmed the excellent durability of the produced FSBM-based extrudates.

Color $\left(\mathrm{L}^{*}, \mathrm{~b}^{*}, \mathrm{a}^{*}\right)$ : As shown in Table 4, FM replacement with FSBM in the rainbow trout diet at both levels of $80 \%$ and $100 \%$ substantially raised $a^{*}$ and $b^{*}$ values of the extrudates by $36 \%, 73 \%, 10 \%$, and $30 \%$ compared with those of the fish meal-based diet, respectively; only total replacement of FM with FSBM increased the L* value of the extrudate (by 12.52\%). Color is an important visual quality of biological products (Ilo and Berghofer, 1999). Changes in color of food products during thermal processing can be attributed to the effect of Maillard reactions (Mercier et al., 1989) which reduces lysine availability of the protein-based products through the blockage of basic essential amino acids, mainly lysine, and formation of amadori lysine complexes such as furosine, leading to lysine unavailability (Finot, 1982; Bjorck and Asp 1983; Bjorck et., 1985). Maillard reactions occurring during the extrusion processing may destruct amino acid chains and corrupt their sequence conformation (Rosentrater et al., 2005; Dahland Villota, 1991), and thus affect the protein functionality as well as reduce the protein digestibility. Chevanan et al (2007a) indicated that shifting in color scores of extrudates compared to raw blends could be due to multiple factors, such as lysine loss or alteration, protein denaturation, as well as differences in raw ingredients. 


\section{Conclusions}

Increasing levels of microbial fermented soybean meal (FSBM) from $0 \%$ to $100 \%$ in vegetable- based blends resulted in more expanded extrudates. FSBM incorporation increased WSI values curvilinearly and decreased the BD of the extrudates. All the extrudates had excellent durability, floatability, and storage stability. Overall FSBM is a promising protein alternative for the aquaculture industry. Yet, more research needs to be done to examine the effect of extrusion processing parameters on properties of the FSBM-based diets as well as nutritional efficacy by conducting performance trials. In fact, these extrudates were used for subsequent fish growth trials (data published elsewhere).

\section{Acknowledgements}

The research was financed by the United States Department of Agriculture, Agricultural Research Service.

The authors thank the Agricultural Experiment Station, South Dakota State University, and the North Central Agricultural Research Laboratory, USDA-ARS, Brookings, South Dakota, for funding, facilities, equipment and supplies. Furthermore, the cooperation and assistance of Sharon Nichols, Christine Wood, Mike Barnes, and Riley Morgan is greatly appreciated.

\section{References}

ADCP (Aquaculture Development and Coordination Programme). (1983). Fish feeds and feeding in developing countries: an interim report on the ADCP Feed Development Programme. FAO Project INT/81/031 Aquaculture Development and Coordination Programme, FAO Field Document No. ADCP/REP/83/18, FAO, Rome, pp. 100.

Adeparusi, E. O., \& Famurewa, J. A. V. (2011). Water Temperature and Surface Coating Effect on Floatability, Water Absorption and Thickness Swelling of Feed. Journal of Agricultural Science, 3(4), 254-260.

Alavi, S. H., Gogoi, B. K., Khan, M., Bowan, B. J., \& Rizvi, S. S. H. (1999). Structural properties of protein stabilized starch-based supercritical fluid extrudates. Food Research International, 32, 107-118. http://dx.doi.org/10.1016/S0963-9969(99)00063-0

Ali, S. A. (1988). Water stability of prawn feed pellets prepared using different binding materials with special reference to tapioca. Ind. J. Fish, 35(1), 46-51.

Alves, R. M. L., Grossmann, M. V. E., \& Silva, R. S. S. F. (1999). Gelling properties of extruded yam (Dioscorea alota) starch. Food Chem., 67, 123-127. http://dx.doi.org/10.1016/S0308-8146(99)00064-3.

Amaya, E. A., Davis, D. A., \& Rouse, D. B. (2007). Replacement of fishmeal in practical diets for the Pacific white shrimp (Litopenaeus vannamei) reared under pond conditions. Aquaculture, 262, 393-401. http://dx.doi.org/10.1016/j.aquaculture.2006.11.015

Anderson, R. A. (1982). Water absorption and solubility and amylograph characteristics on roll cooked small grain products. Cereal Chem., 59, 265-269.

AOAC. (2003). Official Methods of Analysis of AOAC International. 17th Ed. AOAC International: Gaithersburg, MA.

Arámbula-Villa, G., Guitiérrez-Árias, E., \& Moreno-MartÍnez, E. (2007). Thermal properties of maize masa and tortillas with different components from maize grains, and additives. Journal of Food Engineering, 80(1), 55-60. http://dx.doi.org/10.1016/j.jfoodeng.2006.05.004

Arndt, R. E, Hardy, R.W., Sugiura, S. H., \& Dong, F. M. (1999). Effects of heat treatment and substitution level on palatability and nutritional value of soy defatted flour in feeds for Coho salmon, Oncorhynchus kisutch. Aquaculture, 180, 129-145. http://dx.doi.org/10.1016/S0044-8486(99)00186-6

ASAE. (2004). American Society of Agricultural Engineers Standards, Engineering Practices and Data. The Society: St. Joseph, MI.

Ayadi, F.Y, Fallahi, P., Muthukumarappan, K., \& Rosentrater, K. A. (2011a). Single-screw extrusion modeling effects on extrusion processing parameters and physical properties of DDGS-based Nile tilapia (Oreochromis niloticus) feeds. ASABE Annual International Meeting 2011. Louisville, Kentucky. No.1110885. August 7-10.

Ayadi, F. Y., Muthukumarappan, K., Rosentrater, K. A., \& Brown, M. L. (2011b). Single-screw extrusion processing of distillers dried grains with solubles (DDGS)-based yellow perch (Perca flavescens) feeds. Cereal Chem., 88, 179-188. http://dx-doi.org/10.1094/CCHM.08100118 
Ayadi, F. Y., Rosentrater, K. A., Muthukumarappan, K., \& Brown, M. L. (2011c). Twin-screw extrusion processing of distillers dried grains with solubles (DDGS)-based yellow perch (Perca flavescens) feeds. Food Biopr. Technol. http://dx.doi.org/10.1007s11947 01105355

Ayadi, F. Y., Muthukumarappan, K., Rosentrater, K. A., \& Brown, M. L. (2011d). Twin-screw extrusion processing of rainbow trout (Oncorhynchus mykiss) feeds using various levels of corn-based distillers dried grains with solubles (DDGS). Cereal Chem., 88, 363-374. http://dx.doi.org/10.1094/CCHEM-08-10-0120

Badrie, N., \& Mellowes, W. (1991). Effect of extrusion variables on cassava extrudate. J. Food Sci., 56(5), 1334-1337. http://dx.doi.org/10.1111/j.1365-2621.1991.tb04766.x

Banerjee, S., \& Chakraborty, P. (1998). Physico-chemical properties of extruded aquatic feed. Ind. J. Fish, 45, 107-111.

Beauchat, L. R. (1981). Microbial stability as affected by water activity. Cereal Foods World, 26, 345-349.

Berset, C. (1989). Color. In: C. Mercier, P. Linko, \& J. M. Harper (Eds.), Extrusion cooking (pp. 371-385). St. Paul, MN: AACC.

Bhattacharya, S. (1997).Twin-screw extrusion of rice-green gram blend: Extrusion and extrudate characteristics. Journal of Food Engineering, 32(1), 83-99. http://dx.doi.org/10.1016/S0260-8774(97)00004-6

Bhattacharya, M., \& Hanna, M. A. (1986). Viscosity modeling of dough in extrusion. J. Food Process Eng., 2, 337-342.

Bjorck, I., \& Asp, N. G. (1983). The effects of extrusion cooking on nutritional value. A literature review. J. Food Eng., 2, 281-308. http://dx.doi.org/10.1016/0260-8774(83)90016-X

Bjorck, I., Matoba, T., \& Nair, B. M. (1985). In vitro enzymatic determination of the protein nutritional value and the amount of available lysine in extruded cereal-based products. Agricultural and Biological Chemistry Tokyo, 49, 945-951. http://dx.doi.org/10.1271/bbb1961.49.945

Blanche, S., \& Sun, X. (2004). Physical characterization of starch extrudates as a function of melting transitions and extrusion conditions. Advances in Polymer Technology, 23(4), 277-290. http://dx.doi.org/10.1002/adv.20017

Bouzaza, D., Arhaliass, A., \& Bouvier, J.M. (1996). Die design and dough expansion in low moisture extrusion-cooking process. Journal of Food Engineering, 29(2), 139-152. http://dx.doi.org/10.1016/0260-8774(95)00076-3

Bouvier, J. M., \& Brisset, A. (2006). Aquafeed twin screw extrusion processing. Asian Aquafeeds: Current Developments in the Aquaculture Feed Industry. Malaysian Fisheries Society Occasional Publication No. 13, Kuala Lumpur, Malaysia. pp. 76-104. Retrieved from http://affris.org/tilapia/tables/pdf/bouvier.pdf

CAES (College of Agricultural and Environmental Sciences). (1994). Trout Production. In: G. W. Lewis, \& J. R. Gilbert, (Eds.), Aquaculture Technical series. The University of Georgia, CAES Publications. Retrieved from http://warnell.forestry.uga.edu/service/library/ats-5/ats-5.pdf

Cavalcanti, W. B., \& Behnke, K. C. (2005a). Effect of composition of feed model system on pellet quality: a mixture experimental approach. I. Cer. Chem., 82, 455-461. http://dx.doi.org/10.1094/CC-82-0455

Cavalcanti, W. B., \& Behnke, K. C. (2005b). Effect of composition of feed model systems on pellet quality: a mixture experimental approach. II. Cer. Chem., 82, 462-467. http://dx.doi.org/10.1094/CC-82-0462

Chang, Y. K., \& Wang, S. S. (1999). Advances in Extrusion Technology: Aquaculture Animal Feeds and Foods. Technomic Publishing Company, Inc., Lancaster, PA.

Choi, Y., \& Okos, M. R. (1986). Effects of temperature and composition on the thermal properties of foods. In: M. A. Rao, and S. S. H. Rizvi, (Eds.), Food Engineering and Process Applications: Transport Phenomena (pp. 93-101). Elsevier Applied Science Publishers, Great Britain, London..

Chauhan, G. S., \& Bains, G. S. (1988). Effect of some extruder variables on physico-chemical properties of extruded rice-legume blends. Food Chemistry, 27(3), 213-224.

Cheng, Z. J., \& Hardy, R. W. (2004). Nutritional value of diets containing distiller's dried grain with solubles for rainbow trout, Oncorhynchus mykiss. Journal of Applied Aquaculture, 15, 101-113.

Chevanan, N., Muthukumarappan, K., Rosentrater, K. A., \& Julson, J. L. (2007a). Effect of die dimensions on extrusion processing parameters and properties of DDGS-based aquaculture feeds. Cereal Chem., 84, 389. http://dx.doi.org/10.1094/CCHEM-84-4-0389 
Chevanan, N., Rosentrater, K. A., \& Muthukumarappan, K. (2007b). Twin-screw extrusion processing of feed blends containing distillers dried grains with solubles (DDGS). Cereal Chem., 84(5), 428-436. http://dx.doi.org/10.1094/CCHEM-84-5-0428

Chevanan, N., Muthukumarappan, K., \& Rosentrater, K. A. (2007c). Neural network and regression modeling of extrusion processing parameters and properties of extrudates containing DDGS. Transactions of the ASABE, 50(5), 1765-1778.

Chevanan, N., Rosentrater, K. A., \& Muthukumarappan, K. (2008). Effect of DDGS, moisture content, and screw speed on physical properties of extrudates in single-screw extrusion. Cereal Chem., 85(2), 132-139. http://dx.doi.org/10.1094/CCHEM-85-2-0132.

Chevanan, N., Muthukumarappan, K., \& Rosentrater, K. A. (2009). Extrusion studies of aquaculture feed using distillers dried grains with solubles and whey. Food and Bioprocess Technology, 2(2), 177-185. http://dx.doi.org/10.1007/s11947-007-0036-8

Chevanan, N., Rosentrater, K. A., \& Muthukumarappan, K. (2010). Effects of processing conditions on single screw extrusion of feed ingredients containing DDGS. Food and Bioprocess Technology, 3, 111-120.

Colonna, P., \& Mercier, C. (1983). Macromolecular modifications of manioc starch components by extrusion-cooking with and without lipids. Carbohydr. Polym, 3(2), 87-108. http://dx.doi.org/10.1016/0144-8617(83)90001-2

Colonna, P., Tayeb, J., \& Mercier, C. (1989). Extrusion cooking of starch and starchy products. In: C. Mercier, P. Linko, \& J. M. Harper (Eds.), Extrusion Cooking (pp. 247-320). AACC International, St. Paul, MN.

Coyle, S. D., Mengel, G. J., Tidwell, J. H., \& Webster, C. D. (2004). Evaluation of growth, feed utilization, and economics of hybrid tilapia, Oreochromis niloticus $\times$ Oreochromis aureus, fed diets containing different protein sources in combination with distillers dried grains with solubles. Aquaculture Research, 35, 365-370.

Dabrowski, K., Poczyczynski, P., Köck, G., \& Berger, B. (1989). Effect of partially or totally replacing fishmeal protein by soybean meal protein on growth, food utilization and proteolytic enzyme activities in rainbow trout (Salmo gairdneri). New in vivo test for exocrine pancreatic secretion. Aquaculture, 77(1), 29-49. http://dx.doi.org/10.1016/0044-8486(89)90019-7

Dahl, S. R., \& Villota, R. (1991). Effect of thermal denaturation on the texturization of soybean protein through twin-screw extrusion. J. Can. Inst. Sci. Technol., 24, 143-150.

Ding, Q.-B., Ainsworth, P., Tucker, G., \& Marson, H. (2005). The effect of extrusion conditions on the physicochemical properties and sensory characteristics of rice-based expanded snacks. Journal of Food Engineering, 66(3), 283-289.

Edwards, R. H., Becker, R., Mossman, A. P., Gray, G. M., \& Whitehand, L. C. (1994). Twin-screw extrusion cooking of small white beans (Phaseolus vulgaris). Lebensmittel-Wissenschaft und-Technologie, 27(5), 472-481.

El-Saidy, D. M. S. D., \& Gaber, M. M. A. (2002). Complete replacement of fishmeal by soybean meal with dietary L-lysine supplementation for Nile tilapia Oreochromis niloticus (L.) fingerlings. J. World Aquac. Soc., 33, 1119-1127. http://dx.doi.org/10.1111/j.1749-7345.2002.tb00506.x

Fallahi, P., Rosentrater, K. A., Muthukumarappan, K., \& Tulbek, M. (2011). Effects of conditioner steam, extruder water and screw speed on physical properties of DDGS-based extrudates in twin-screw extrusion. 2011 ASABE Annual International Meeting. Louisville, Kentucky.

Fan, J., Mitchell, J. R., \& Blanshard, J. M. V. (1994). A computer simulation of the dynamics of bubble growth and shrinkage during extrudate expansion. Journal of Food Engineering, 23(3), 337-356. http://dx.doi.org/10.1016/0260-8774(94)90058-2

Faubion, J. M., Hoseney, R. C., \& Seib, P. A. (1982). Functionality of grain components in extrusion. Cereal Foods World, 27, 212-216.

FDS (Feed Development Section). (1994). Feeds and feeding of milkfish, Nile tilapia, Asian sea bass, and tiger shrimp. Aquaculture Extension Manual No.21, Southeast Asian Fisheries Development Center, SEAFDEC Aquaculture Department, Tigbauan, Iloilo, Philippines. pp. 97.

Fernandez-Gutierrez, J. A., Martin-Martinez, E. S., Martinez-Bustos, F., \& Cruz-Orea, A. (2004). Physicochemical properties of casein-starch interaction obtained by extrusion process. Starch - Starke, 
56(5), 190-198.

Finot, P. A. (1982). Nonenzymatic browning products: physiologic effects and metabolic transit in relation to chemical structure. A review. Diabetes, 31, 22-28.

Floreto, E. A. T., Bayer, R. C., \& Brown, P. B. (2000). Effects of soybean based diets, with and without amino acid supplementation, on growth and biochemical composition of juvenile American lobster, Homarus americanus. Aquaculture, 189, 211-235. http://dx.doi.org/10.1016/S0044-8486(00)00363-X

Ganesan, V., Muthukumarappan, K., \& Rosentrater, K. A. (2008). Effect of moisture content and soluble level on the physical, chemical, and flow properties of distillers dried grains with solubles (DDGS). Cereal Chem., 85(4), 464-470. http://dx.doi.org/10.1094/CCHEM-85-4-0464

Gokulakrishnan, P., \& Bandyopadhyay, S. (1995). Formulation and characterization of some pelleted feeds for Penaeus monodon. Fish. Technol., 32(1), 19-24.

Gomes, Emídio F., Rema, P., Gouveia, A., \& Teles, A. O. (1995). Replacement of fishmeal by plant proteins in diets for rainbow trout (Oncorhynchus mykiss), Effect of the quality of the fishmeal based control diets on digestibility and nutrient balances. Water Science and Technology, 31(10), 205-211.

Govindasamy, S., Campanellab, O. H., \& Oatesa, C. G. (1996). High moisture twin-screw extrusion of sago starch: 1. Influence on granule morphology and structure. Carbohydr. Polym., 30(4), 275-286. http://dx.doi.org/10.1016/S0144-8617(96)00024-0

Guy, R. (2001). Extrusion Cooking: Technologies and Applications. Woodhead Publishing Limited and CRC Press LLC, Cambridge, UK. pp. 89.

Hardy, R. W. (2010). Utilization of plant proteins in fish diets: effects of global demand and supplies of fishmeal. Aquaculture Research, 41, 770-776.

Hardy, R. W. (2002). Use of soybean meal in diets of salmon and trout. United Soybean Board, Chesterfield, MO, and American Soybean Association. St. Louis, MO, USA.

Hardy, R. W., \&Masumoto, T. (1990). Specifications for marine by-products for aquaculture. In: S. Keller (Eds.), Alaska Sea Grant College Program. Proc. Int. Conf. on Fish By-products (pp. 109-120). Anchorage, AK.

Harper, J. M. (1989). Food extruders and their applications. In: C. Mercier, P. Linko, \& J. M. Harper (Eds.), Extrusion Cooking (pp.1-15). St. Paul, MN: American Association of Cereal Chemists.

Heldman, D. R. (2003). Encyclopedia of Agricultural, food, and Biological Engineering. CRC Press, Technology and Engineering. pp. 1004.

Higl, B., Kurtmann, L., Carlsen, C. U., Ratjen, J., Först, P., Skibsted, H. L., Kulozik, U., \& Risbo, J. (2007). Impact of water activity, temperature, and physical state on the storage stability of Lactobacillus paracasei ssp. paracasei freeze-dried in a lactose matrix. Biotechnology Progress, 23(4), 794-800

Hong, K. J., Lee, C. H., \& Kim, S. W. (2004). Aspergillus oryzae GB-107 fermentation improves nutritional quality of food soybeans and feed soybean meals. J. Med. Food, 4, 430-435. http://dx.doi.org/10.1089/jmf.2004.7.430

Ibanoglu, S., Paul, A., \& George, D. H. (1996). Extrusion of tarhana: Effect of operating variables on starch gelatinization. Food Chem., 57, 541-544. http://dx.doi.org/10.1016/S0308-8146(96)00047-7

Ilo, S., \& Berghofer, E. (1999). Kinetics of color changes during extrusion cooking of maize grits. J food Eng., 39(1), 73-80. http://dx.doi.org/10.1016/S0260-8774(98)00148-4

Jamin, F. F., \& Flores, R. A. (1998). Effect of separation and grinding of corn dry-milled streams on physical properties of single-screw low speed extruded products. Cereal Chemistry, 75, 775-779. http://dx.doi.org/10.1094/CCHEM.1998.75.6.775

Johansson, J. R. (1978). Know your material-How to predict and use the properties of bulk solids. Chem. Eng.: Desk book issue. 9-17.

Jauncey, K., \& Ross, B. (1982). Nutritional terminology. A guide to tilapia feeds and feeding. Institute of aquaculture, University of Stirling, Scotland. pp. 95-100.

Kannadhason, S., Muthukumarappan, K., \& Rosentrater, K. A. (2009b). Effects of ingredients and extrusion parameters on aquafeeds containing DDGS and tapioca starch. Journal of Aquaculture Feed Science and Nutrition, 1(1), 6-21. 
Kannadhason, S., Muthukumarappan, K., \& Rosentrater, K. A. (2009a). Effect of starch sources and protein content on extruded aquaculture feed containing DDGS. Food and Bioprocess Technology.

Kannadhason, S., Rosentrater, K. A., \& Muthukumarappan, K. (2010). Twin screw extrusion of DDGS based aquaculture feeds. Journal of the World Aquaculture Society, 41(51), 1-15.

Kaushik S. J., Cravedi J. P., Lalles J. P., Sumpter J., Fauconneau B., \& Laroche M. (1995). Partial or total replacement of fishmeal by soybean protein on growth, protein utilization, potential estrogenic or antigenic effects, cholesterolemia and flesh quality in rainbow trout, Oncorhynchus mykiss. Aquaculture, 133(3-4), 257-274.

Kawasaki, T., \& Kawai, S. (2006). Thermal insulation properties of wood-based sandwich panel for use as structural insulated walls and floors. Journal of Wood Science, 52(1), 75-83. http://dx.doi.org/10.1007/s10086-005-0720-0

Kim, B. N., Yang, J. L., \& Song, Y. S. (1999). Physiological functions of chongkukjang. Food and Nutrition, 4, 40-46.

Kim, K. I., Kayes, T. B., \& Amundson, C. H. (1991). Purified diet development and reevaluation of the dietary protein requirement of fingerling rainbow trout (Oncorhynchus mykiss). Aquaculture, 96, 57-67.

Koop, T., Luo, B., Tsias, A., \& Peter, T. (2000). Water activity as the determinant for homogeneous ice nucleation in aqueous solutions. Nature, 406(6796), 611-614. http://dx.doi.org/10.1038/35020537

Lam, C. D., \& Flores, R. A. (2003). Effect of particle size and moisture content on viscosity of fish feed. Cereal Chem., 80, 20-24. http://dx.doi.org/10.1094/CCHEM.2003.80.1.20

Lim, S. J., \& Lee, K. J. (2009). Partial replacement of fishmeal by cottonseed meal and soybean meal with iron and phytase supplementation for parrot fish Oplegnathus fasciatus. Aquaculture, 290, 283-289. http://dx.doi.org/10.1016/j.aquaculture.2009.02.018

Lin, S., Hsieh, F., \& Huff, H. E. (1998). Effects of lipids and processing conditions on lipid oxidation of extruded dry pet food during storage. Anim. Feed Sci. Technol., 71, 283-294. http://dx.doi.org/10.1016/S0377-8401(97)00157-0

Lin, S., Huff, H. E., \& Hsieh, F. (2000). Texture and chemical characteristics of soy protein meat analog extruded at high moisture. J. Food Sci., 65, 264-269. http://dx.doi.org/10.1111/j.1365-2621.2000.tb15991.x

Marine Aquaculture Task Force. (2007). Sustainable marine aquaculture: Fulfilling the promise. Managing the risks. Report of the Marine Aquaculture Task Force, Woods Hole Oceanographic Institution. Takoma, Park, MD, pp. 93. Retrieved from

http://www.pewtrusts.org/uploadedFiles/wwwpewtrustsorg/Reports/Protecting_ocean_life/Sustainable_Mar ine_Aquaculture_final_1_07.pdf

Mason, W. R., \&. Hoseney, R. C. 1986). Factors affecting the viscosity of extrusion cooked wheat starch. Cereal Chem., 63(5), 436-441.

Mathew, J. M., Hoseney, R. C., \& Faubion, J. M. (1999a). Effects of corn sample, mill type, and particle size on corn curl and pet food extrudates. Cer. Chem., 76, 621-624. http://dx.doi.org/10.1094/CCHEM.1999.76.5.621

Mathew, J. M., Hoseney, R. C., \& Faubion, J. M. (1999c). Effect of corn moisture on the properties of pet food extrudates. Cer. Chem., 76, 953-956. http://dx.doi.org/10.1094/CCHEM.1999.76.6.953

Mathew, J. M., Hoseney, R. C., \& Faubion, J.M. (1999b). Effects of corn hybrid and growth environment on corn curl and pet food extrudates. Cer. Chem., 76, 625-628. http://dx.doi.org/10.1094/CCHEM.1999.76.5.625

Menegassia, B., Pilosofb, A. M. R., \& José, A. G. (2011). Comparison of properties of native and extruded amaranth (Amaranthus cruentus L. - BRS Alegria) flour. LWT - Food Science and Technology, 44(9), 1915-1921. http://dx.doi.org/10.1016/j.lwt.2011.04.008

Mercier, C., Linko, P., \& Harper, J. M. (1989). Extrusion Cooking. AACC International: St. Paul, MN.

Miller, R. C. (1985). Low moisture extrusion: Effects of cooking moisture on product characteristics. J. Food Sci., 50, 249-253.

Mitchell, J. R., Fan, J., \& Blanshard, J. M. V. (1994). The shrinkage domain. Extrusion Communiqué March, $10-12$. 
Mjoun, K., \& Rosentrater, K. A. (2011). Extruded aquafeeds containing distillers dried grains with solubles: effects on extrudate properties and processing behaviour. Journal of the Science of Food and Agriculture, 91(15), 2865-2874. http://dx.doi.org/10.1002/jsfa.4536

Moore, D., Sanei, A., Van Hecke, E., \& Bouvier, J. M. (1990). Effect of ingredients on physical/structural properties of extrudates. J. Food Sci., 55, 1383-1387

Moscicki, L., \& van Zuilichem, D. J. (1983). Animal feed applications of extrusion cooking and a Polish example. Journal of Food Engineering, 2(3), 211-223.

Naylor, R., \& Burke, M. (2005). Aquaculture and ocean resources: Raising tigers of the sea. Annual Review of Environment and Resources, 30, 185-218. http://dx.doi.org/10.1146/annurev.energy.30.081804.121034

Nielsen, E. (1976). Whole seed processing by extrusion cooking. J. AOCS, 53, 305-309. http://dx.doi.org/10.1007/BF02605709

NOAA. (2010). National Oceanic and Atmospheric Administration. U.S. Seafood Consumption Declines Slightly in 2009. Retrieved from http://www.noaanews.noaa.gov/stories2010/20100909_consumption.html

NOAA. (2012). National Oceanic and Atmospheric Administration. Imports and Exports of Fishery Products Annual Summary, 2011. Retrieved from http://www.st.nmfs.noaa.gov/st1/trade/documents/TRADE2011.pdf

Oliveira, M. A., Moller, H. S., Haaland, H., \& Rosenlund, G. (1992). The effect of process parameters on expansion of extruded fish feed. In: J. L. Kokini, C. T. Ho, \& M. V. Karwe (Eds.), Food Extrusion Science and Technology. Marcel Dekker: New York.

Olli, J. J., \& Krogdahl, A. E. (1994). Nutritive value of four soybean products as protein sources in diets for rainbow trout (Oncorhynchus mykiss, Walbaum) reared in fresh water. Acta Agric. Scand. Sect. A. Anim. Sci., 44, 185-192.

Peres, H., Lim, C., \& Klesius, P. H. (2003). Nutritional value of heat-treated soybean meal for channel catfish (Ictalurus punctatus). Aquaculture, 225, 67-82. http://dx.doi.org/10.1016/S0044-8486(03)00289-8.

Pongmaneerat, J., \& Watanabe, T. (1992). Utilization of soybean meal as protein source in diets for rainbow trout. Nippon Suisan Gakkaishi, 58, 1983-1990.

Pritchard, G. I. (1976). Structured Aquaculture Development with a Canadian Perspective. J. Fish. Res. Bd. Can., 33, 855-870. http://dx.doi.org/10.1139/f76-108

Rauwendaal, C. J. (2004). Analysis and experimental evaluation of twin screw extruders. Polymer Engineering and Science, 2(16), 1092-1100. http://dx.doi.org/10.1002/pen.760211608

Refstie, S., Sahlstr"om, S., Brathen, E., Baeverfjord, G., \& Krogedal, P. (2005). Lactic acid fermentation eliminates indigestible carbohydrates and antinutritional factors in soybean meal for Atlantic salmon (Salmo salar). Aquaculture, 246, 331-345.

Riaz, M. N. (2000). Extruders in Food Applications. Lancaster, PA: Technomic Publishing.

Rolfe, L. A., Huff, H. E., \& Hsieh, F. (2000). The effect of processing conditions on the quality of extruded catfish feed. Trans. ASAE, 43, 1737-1743.

Rolfe, L. A., Huff, H. E., \& Hsieh, F. (2001). Effects of particle size and processing variables on the properties of an extruded catfish feed. J. Aquatic Food Product Technol., 10(3), 21-33.

Romarheim, O. H., Skrede, A., Gao, Y., Krogdahl, Å., Denstadli, V., Lilleeng, E., \& Storebakken, T. (2006). Comparison of white flakes and toasted soybean meal partly replacing fishmeal as protein source in extruded feed for rainbow trout (Oncorhynchus mykiss). Aquaculture, 256, 354-364. http://dx.doi.org/10.1016/j.aquaculture.2006.02.006

Rosentrater, K. A., Richard, T. L., Bern, C. J., \& Flores, R. A. (2005). Small scale extrusion of corn masa byproducts. Cereal Chem., 82, 436-446. http://dx.doi.org/10.1094/CC-82-0436

Rosentrater, K. A., Muthukumarappan, K., \& Kannadhason, S. (2009a). Effects of ingredients and extrusion parameters on aquafeeds containing DDGS and potato starch. J. Aquac. Feed Sci. Nutr., 1, 22-38.

Rosentrater, K. A., Muthukumarappan, K., \& Kannadhason, S. (2009b). Effects of ingredients and extrusion parameters on properties of aquafeeds containing DDGS and corn starch. J. Aquac. Feed Sci. Nutr., 1, $39-43$.

Rosentrater, K. A., \& Tulbek, M. (2010). Extrusion of aquafeeds containing corn distillers dried grains with 
solubles (DDGS) for Nile tilapia. Aquaculture America 2010. San Diego, California. March 1-5.

Rout, R. K. (1997). Studies on extrusion cooking in relation to shrimp feed processing. Ph.D. Thesis. Indian Institute of Technology. Kharagpur, India.

Rumsey, G. L., Hughes, S. G., \& Winfree, R. A. (1993). Chemical and nutritional evaluation of soya protein preparations as primary nitrogen sources for rainbow trout (Oncorhynchus mykiss). Anim. Feed Sci. Technol., 40, 135-151. http://dx.doi.org/10.1016/0377-8401(93)90152-A

Sandra, H. P. F., \& Jose, A. G. A. (1993). Effect of phospholipid on protein structure and solubility in the extrusion of lung proteins. Food Chem. 47:111-119. http://dx.doi.org/10.1016/0308-8146(93)90230-D

Shi, Z.H. \& L.A. Utracki. (1992). Development of polymer blend morphology during compounding in a twin-screw extruder. Part II: Theoretical derivations. Polymer Engineering and Science, 32(24), 1834-1845.

Shimeno, S., Hashimoto, A., Ando, Y., \& Hayakawa, K. (1994). Improving the nutritive value of defatted soybean meal through purification and fermentation for fingerling yellowtail. Suisanzoshoku, 42, 247-252.

Smith, R. R. (1977). Recent research involving full-fat soybean meal in salmonid diets. Salmonid., 1, 8-18.

Smith, R. R., Kincaid, H. L., Regenstein, J. M., \& Rumsey, G. L. (1988). Growth, carcass composition, and taste of rainbow trout of different strains fed diets containing primarily plant or animal protein. Aquaculture, 70, 309-321.

Singh, R. K., Nielsen, S. S., \& Chambers, J. V. (1991). Selected characteristics of extruded blends of milk protein raffinate or nonfat dry milk with corn flour. J. Food Process. Preserv., 15, 285-302. http://dx.doi.org/10.1111/j.1745-4549.1991.tb00173.x

Sokhey, A. S., Kollengode, A. N., \& Hanna, M. A. (1994). Screw configuration effects on corn starch expansion during extrusion. J. Food Sci., 59, 895-899. http://dx.doi.org/10.1111/j.1365-2621.1994.tb08152.x

Steel, C. J., Sgarbieri, V. C., \& Jackix, M. H. (1995). Use of extrusion technology to overcome undesirable properties of hard-to-cook dry beans (Phaseolus vulgaris L.). J. Agric. Food Chem., 43(9), 2487-2492.

Sun, Y., \& Muthukumarappan, K. (2002). Changes in functionality of soy-based extrudates during single screw extrusion processing. International Journal of Food Properties, 5(2), 379-389.

Tumuluru, J. S., \& Sokhansanj, S. (2008). Optimization of aqua feed pellet properties using genetic algorithm. ASABE Annual International Meeting. Providence, Rhode Island.

Tunison, A. V., Philips, A. M., \& Brockway, D. R. (1941). The Nutrition of Trout. Fisheries Research Bulletin, 1(10), 3-20.

Van Eys, J. E., Offner, A., \& Bach, A. (2004). Manual of Quality Analyses for Soybean Pro-ducts in the Feed Industry. American Soy-bean Association United Soybean Board, USA.

Venegas-Calerón, M. O., Sayanova, O., \& Napier, J. A. (2010). An alternative to fish oils: metabolic engineering of oil-seed crops to produce omega-3 long chain polyunsaturated fatty acids. Progress in Lipid Research, 49, 108-119.

Watanabe, T., Kiron, V., \& Satoh, Sh. (1997). Trace minerals in fish nutrition. Aquaculture, 151, 185-207.

Wilson, R. P. (1989). Amino acids and proteins. In: D. San, \& J. E. Halver (Eds.), Fish Nutrition (pp.112-151). California: Academic Press Inc.

Wilson, R. P., \& Poe, W. E. (1985). Effects of feeding soybean meal with varying trypsin inhibitor activities on growth of fingerling channel catfish. Aquaculture, 46, 19-25. http://dx.doi.org/10.1016/0044-8486(85)90171-1

Wood, J. (1995). Selecting equipment for producing farm-made aquafeeds. In: M. B. New, A. J. G. Tacon, \& I. Csavas (Eds.), Farm-made Aquafeeds (pp.135-147). FAO, Rome, FAO Fisheries Technical.

Yuan, Y. C., Lin, Y. C., Yang, H. J., Gong, Y., Gong, S. Y., \& Yu, D. H. (2012). Evaluation of fermented soybean meal in the practical diets for juvenile Chinese sucker, Myxocyprinus asiaticus. Aquaculture Nutrition. http://dx.doi.org/10.1111/j.1365-2095.2012.00939.x

Zhou, F., Song, W., Shao, Q., Peng, X., Xiao, J., Hua, Y., Owari, B. N., Zhang, T., \& Ng, W.-K. (2011). Partial Replacement of Fishmeal by Fermented Soybean Meal in Diets for Black Sea Bream, Acanthopagrus schlegelii, Juveniles. Journal of the World Aquaculture Society, 42, 184-197.

doi:10.1111/j.17497345.2011.00455.x 
Zuilichem, D. J. V., \& Stolp, W. (1984). Engineering aspects of single and twin screw extrusion cooking of biopolymers. In: R. Jowitt (Eds.), Extrusion Cooking Technology. Elsevier Applied Sciences: London.

\section{Copyrights}

Copyright for this article is retained by the author(s), with first publication rights granted to the journal.

This is an open-access article distributed under the terms and conditions of the Creative Commons Attribution license (http://creativecommons.org/licenses/by/4.0/). 